Contents Vol. 44, 1981

\title{
Applied Neurophysiology
}

Official Journal of the World Society for Stereotactic and Functional Neurosurgery Founded 1938 as 'Confinia Neurologica' by E.A. Spiegel

EdHorf ${ }^{\text {on }}$

Ph.L. Gildenberg, Houston, Tex.

Editorial Assistant:

Patricia O. Franklin, Houston, Tex. 
Editorial Board:

E. Eidelberg, San Antonio, Tex.

S. Gilman, Ann Arbor, Mich.

R.G. Grossman, Galveston, Tex.

R. Hassler, Frankfurt a.M.

L. Laitinen, Bergen J.W. Lance, Little Bay, Australia D.M. Long, Baltimore, Md. R. Marino. Jr., S5o Paulo

F. Mundinger, Freiburg i.Br. 
H. Narabayashi, Tokyo

B.S. Nashold, Jr., Durham, N.C.

M. Rayport, Toledo, Ohio

J. Siegfried, Zurich

A. Struppler, Munich

R.R. Tasker, Toronto

J.U. Toglia, Philadelphia, Pa.

J.M. Van Buren, Miami, Fla.

A.A. Ward, Jr.. Seattle, Wash.

N. Zervas, Boston, Mass.

S. Karger $\bullet$ Basel $\bullet$ Miinchen $\bullet$ Paris $\bullet$ London $\bullet$ New York $\bullet$ Sydney 



\title{
Contents
}

\author{
No. 1-3
}

Proceedings of the Third International Meeting on Spinal Cord Stimulation

Houston, Tex., May, 1980

Editor: Philip L. Gildenberg, Houston, Tex.

Physiology of Motor Control in Man

Eccles, J.C

Possible Modes of Action of Extradural Electrical Stimulation on the Spinal Cord

Phillips, C.G.

Propriospinal Mechanisms Involved in the Effects of Spinal Cord Stimulation

Murthy, K.S.K.

Multiple-Lead Spinal Cord Stimulation: Technique (with 1 color plate)

Waltz, J.M.; J.M.; Andreesen, W.H

Beneficial Augmentation following Dorsal Column Stimulation in Some Neurological Diseases

Davis, R.; Gray, E.; Kudzma, J......

Technological Problems of Spinal Cord Stimulation Systems: A Clinical Perspective

Sharkey, P.C

Results of Spinal Cord Stimulation in Multiple Sclerosis

Cook, A.W.; Taylor, J.K.; Nidzgorski, F.

Dorsal Column Stimulation in Multiple Sclerosis: Effects on Bladder, Leg Blood Flow and Peptides

Hawkes, C.H.; Fawcett, D.; Cooke, E.D.; Emson, P.C.; Paul, E.A.; Bowcook, S.A ................................ 62

Treatment of Patients with Degenerative Diseases of the Central Nervous System by Electrical Stimulation of the Spinal Cord

Dooley, D.M.; Nisonson, 1

Electrical Spinal Cord Stimulation for Spastic Movement Disorders

Siegfried, J.; Lazorthes, Y.; Broggi, G

Physiological Effects of Spinal Cord Stimulation: Preliminary Findings

Levity, E.; Rilan, M.; Waltz, J.M.;

Indirect Spinal Cord Stimulation. Some Engineering Viewpoints

Vodovnik, L

Quantification and Documentation of Changes Produced by Spinal Cord Stimulation

Struppler, A.; Struppler, E.

Remarks on Spinal Cord Stimulation and the Placebo Effect

Sharkey, P.C.; Dimitrijevic, M.M.; Campos, R.J.; Dimitrijevic, M.R

Biomedical Engineering Aspects of Spinal Cord Stimulation

Sherwood, A.M 
Underlying Mechanisms of the Effects of Spinal Cord Stimulation in Motor Disorders. A Review of the Discussion

Dimitrijevic, M.R.; Faganel, J.; Young, R.R

Clinical Evaluation of the Effect of Spinal Cord Stimulation on Motor Performance in Patients with Upper Motor Neuron Lesions

Campos, R.J.; Dimitrijevic, M.M.; Faganel, J.; Sharkey, P.C.

Neural Control of Gait: Clinical Neurophysiological Aspects

Dimitrijevic, M.R.; Larsson, L.-E ....

Technical Factors Important to Dorsal Column Stimulation

Davis, R.; Gray, E .....

Hypothetical Role of Long-Loop Reflex Pathways

Delwaide, P.J.; Toulouse, R; Crenna, P.

No. 4

Seminar on Spinal Cord Stimulation for the Control of Pain and Other Neurological Disorders New York, April 1980

Editors: Philip L. Gildenberg, Houston, Tex.; Donlin M. Long, Baltimore, Md.

Examination of Possible Mechanisms by Which Stimulation of the Spinal Cord in Man Relieves Pain Campbell, J.N

Stimulation of the Spinal Neuraxis by Biocompatible Electncal Current in the Human

LeRoy, P.L

Spinal Epidural Electncal Stimulation for Pain Control. Practical Details and Results

Ray, CD...

Electrical Stimulation of the Spinal Cord and Peripheral Nerves for Pain Control. A 10-Year Experience

Long, D.M.; Erickson, D.; Campbell, J.; North, R ....

Electrical Stimulation of the Spinal Cord in Patients with Demyelinating and Degenerative Diseases of the Central Nervous System

Dooley, D.M.; Sharkey, J

Electrical Stimulation of the Conus medullaris to Control the Bladder in Paraplegic Patiënt. A 10-Year Review

Nashold, B.S., Jr.; Friedman, H.; Grimes, J.

Comprehensive Management of Spasmodic Torticollis

Cfttenberg, P.L

Multi-Lead Spinal Cord Stimulation for Control of Motor Disorders

Waltz, J.M.; Reynolds, L.O.; Riklan, M 


\section{No. 5-6}

\section{Original Papers}

The Basal Ganglia-Circa 1982. A Review and Commentary

Mehler, W.R

Electromvographic Activity of Neck Muscles in Patients Affected by Retrocollis under the Influence of Stimulation and Coagulation of the Prestitial Nucleus of the Midbrain

Hassler, R.; Vasilescu, C; Dieckmann, G .....

Touch-Evoked Thaiamic Cellular Activity. The Variabie Position of the Anterior Border of Somesthetic SI Thalamus and Somatotopography

Hardy, T.L.; Bertrand, G.; Thompson, C.J

A Survey of Infections in Stereotactic Surgery

Hood, T.W.; Yap, J.C

Surgical Possibilities for Alleviation of Axial Dyskinesias - Companson with Forced Movements of the Head and Eyes

Stejskal, L.; Vladyka, V.; Tomanek, Z

Transdermal Transcutaneous Electric Nerve Stimulation for Pain: The Search for an Optimal Waveform

Jenkner, F.L.; Schuhfried, F

Lesions Made in the Rabbit Brain to Assist the Design and Use of Electrodes for Amygdalotomy in Man

Levi, F.P.; Girgis, M

Bilateral Improvement in Voluntary Movement after Unilateral Diencephalic Lesions for Parkinsonism Meyer, C.H.A

Cortical-Evoked Responses Before and After Percutaneous Thermocoagulation of Gasserian Ganglion. Preliminary Report

Salar, G.; Job, I.; Mingrino, S.

Radial Nerve Conduction in Patients with Carpal Tunnel Syndrome

Smith, J

\section{Abstracts}

20th Annual Meeting of the Japanese Society for Stereotactic and Functional Neurosurgery. Kyoto, October, 1981

President: Keizo Matsumoto, Tokushima

Dedication to Hartwig Kuhlenbeck

Book Reviews

Author Index 387

Subject Index 